\title{
The Effect Of Intellectual Humility, Multicultural Personality, and Religious Orientation Toward Religious Tolerance On Students Of UIN Syarif Hidayatullah Jakarta
}

\author{
Arif Budiman Al Fariz, Gazi Saloom \\ UIN Syarif Hidayatullah Jakarta \\ Corresponding Author: gazi@uinjkt.ac.id
}

\begin{abstract}
This study aims to determine the influence of intellectual humility, multicultural personality (cultural empathy, open-mindedness, emotional stability, flexibility, and social initiative), religious orientation (quest religiousness, intrinsic religiousness, and extrinsic religiousness) toward religious tolerance on students of the Syarif Hidayatullah State Islamic University of Jakarta. Participants in this study involved 360 students using non-probability sampling as a sampling technique. As for religious tolerance measuring instrument uses a measuring instrument from RT Witenberg`s theory with modified into the scale. The intellectual humility variable uses the Comprehensive Intellectual Humility Scale (CHIS), the multicultural personality variable uses the Multicultural Personality Questionnaire Short Form (the MPQ-SF) and the religious orientation variable uses the Introduction to the New Indices of Religious Orientation (NIRO). The findings show a significant influence between intellectual humility, multicultural personality, and religious orientation toward religious tolerance with a proportion of variance of about $51 \%$. The four significant variables are intellectual humility, cultural empathy, open-mindedness, intrinsic religiousness. While the influence of emotional stability, flexibility, social initiative, quest religiousness, and extrinsic religiousness has no significant effect. multicultural personality and religious orientation toward religious tolerance with a proportion of variance of about $51 \%$. The four significant variables are intellectual humility, cultural empathy, open-mindedness, intrinsic religiousness. While the influence of emotional stability, flexibility, social initiative, quest religiousness, and extrinsic religiousness has no significant effect. multicultural personality and religious orientation toward religious tolerance with a proportion of variance of about $51 \%$. The four significant variables are intellectual humility, cultural empathy, open-mindedness, intrinsic religiousness. While the influence of emotional stability, flexibility, social initiative, quest religiousness, and extrinsic religiousness has no significant effect.
\end{abstract}

Keywords: Intellectual Humility, Multicultural Personality, Religious Orientation, Religious Tolerance

\begin{tabular}{|c|c|c|c|c|}
\hline Submission & Review Process & Revised & Accepted & Published \\
\hline September 16, 2020 & $\begin{array}{c}\text { April 8, 2021 - May } \\
10,2021\end{array}$ & May 20, 2021 & May 24, 2021 & June 30, 2021 \\
\hline
\end{tabular}

\section{Introduction}

Indonesia is a country that has a very diverse life. This can be seen from the variety of ethnicities, cultures, languages, religions, values, norms to political views ranging from Sabang to Merauke. (Noor, 2018). Especially Indonesia has and recognizes five different religions, namely Islam, Christianity \& Catholicism, Buddhism, Hinduism, and Confucianism. To achieve a harmonious life in a diverse life, especially in religious life, an important element is needed to achieve that order (Ministry of Religion RI, 2010). The element in question is religious tolerance (Maimanah, 2013).

The issue of religious tolerance in Indonesia is on the rise, this can be proven by oblique phenomena in the field such as the bombing of churches by Muslims (CNN Indonesia, 2019), burning temples in North Sumatra (Apinino, 2018), as well as a wave of anti-Muslim actions against non-Muslims 
becoming governors in DKI Jakarta (BBC, 2017; Hukmana, 2019). This phenomenon marks the emergency of the issue of religious tolerance in Indonesia because it is not following the country's motto, namely Bhineka Tunggal Ika. Even so, on the other hand, there is still a tolerant phenomenon in religion in Indonesia. For example, the film "the santri" was appointed between Muslims and Christians (Ambassador, 2019) and the acceptance of non-Muslim students at UIN Jakarta and live in peace (Fauzan, 2018). The phenomenon in the field is still lack of awareness of tolerance between religious communities in Indonesia.

According to Witenberg (2007), Tolerance means a conscious acknowledgment to have positive judgments and beliefs that involve the principles of justice, equality, caring, and considering the circumstances of others or respecting each other on the principle of equality despite differences in religion, nationalism, ethnicity, and others. Tolerance is a vital organ as a stable and fair system in life in a pluralist society (Verkuyten, 2010). Because tensions and differences are commonplace in a pluralistic or pluralist society, they need to be accepted and endured in it (Mummendey \& Wenzel, 1999; Verkuyten \& Yogeeswaran, 2016). Even though you don't like it, you still have to show warmth, accept it, and live regularly in it (Allport, 1954; Allport \& Ross, 1967). Therefore, religious tolerance is vital for a harmonious life, especially in Indonesia, which has a variety of different and accepting religions.

Research on religious tolerance has been widely carried out, especially by western researchers. A study conducted on 149 people working on the Turkish Amazon website showed that religious tolerance is influenced by intellectual humility (IH). (Tongeren, Stafford, et al., 2016). Then another researcher revealed that 196 Christian Pastors in the
United States had religious tolerance which was influenced by IH (Hook et al., 2016). Other researchers even state that $\mathrm{IH}$ is an antecedent in religious conflicts and increases religious tolerance in the United States (Zhang et al., 2015). From this study, IH is a good predictor of increasing religious tolerance. This is because by having $\mathrm{IH}$, individuals will be open to differences, can change their views when they are wrong, and also forgive others even though they have different religions. (Hook et al., 2015, 2016). Even so, as far as the author's reading, research on IH in Indonesia has not been touched in predicting religious tolerance.

Korol (2017) found that there is a positive influence between multicultural personality (MP) on ethnic tolerance in Portugal. Research conducted on 270 students in Portugal shows that several dimensions of MP have a significant influence on tolerance, including open-mindedness and flexibility. However, another research conducted by him that positive and significant attitude towards differences is only influenced by openmindedness and social initiative (L. Korol, 2018).

Then another study involving 245 other Portuguese students found that MP had a positive effect on tolerance for differences, and open-mindedness consistently had a positive and significant effect. (LD Korol \& Cabral, 2016). Likewise with research conducted in a different culture such as India. Research conducted on 236 postgraduate students in India showed a significant influence between the dimensions of MP, namely openmindedness and flexibility on religious tolerance by $11 \%$. Looking at the research above, open-mindedness consistently has a positive and significant effect on religious tolerance, but not with other dimensions.

Furthermore, research in the variable religious orientation (RO). The first research conducted on 159 Christian students showed 
that there was an influence between religiousness quests on positive attitudes or tolerance towards non-Christian students. (Tongeren, Hakim, et al., 2016). The research only involves the quest of religiousness because it assumes that people with a religious quest orientation tend to be open to new things and differences (Batson \& Schoenrade, 1991b, 1991a; Francis, 2007).

However, in previous research, it was found that the religiousness quest had nothing to do with tolerance or intolerance (Fisher et al., 1994). Meanwhile, in other studies, religious orientation with extrinsic dimensions or extrinsic religiousness has a significant influence on prejudice or intolerance (Allport \& Ross, 1967).

However, in other studies, it is stated that intrinsic religiousness has a strong prejudice against differences (Tsang \& Rowatt, 2007). Altemeyer (2003) states that prejudice is closely related to having zero tolerance. From this study, the religious orientation variable is interesting to study to predict religious tolerance in the Indonesian context.

The theories used in this study include religious tolerance from Witenberg. According to him, religious tolerance is a conscious positive assessment of differences and respect for others based on equality and fulfills three dimensions, namely fairness, empathy, and reasonableness.(RT Witenberg, 2019; Rivka T. Witenberg, 2007, 2019). Intellectual Humility is defined as being aware of one's shortcomings, especially in self-view, followed by openness to review one's point of view, not being overconfident in a view or idea, respecting the views of others, and not bullying when there is a conflict of thought. (Krumrei-mancuso, 2016; Krumrei-mancuso \& Rouse, 2016).

Then multicultural personality is a detailed measurement of individual aspects of relevant traits when interacting in diversity, where MP has five dimensions, cultural empathy, open-mindedness, emotional stability, flexibility, and social initiative.(Oudenhoven \& Zee, 2002; K. Van Der Zee et al., 2013; KI Van Der Zee \& Oudenhoven, 2000, 2001). While religious orientation is a person's religious orientation by having three dimensions that are used, quest, intrinsic and extrinsic religiousness. (Francis, 2007).

The three variables above in previous studies influence explaining religious tolerance. All variables that are used as predictors, namely intellectual humility, multicultural personality, and religious orientation are internal variables from humans so that their measurement of religious tolerance needs to be raised. These variables also have several nuances of similarity such as openness to different new things, empathy for others, flexibility and always seeing individual motives in behavior. In addition, as far as the authors search, there is still no research that discussed religious tolerance using these three variables. Research on the variables above is mostly tested on samples abroad, so it is very important to see it in the Indonesian context.

Based on the explanation above, it is interesting to conduct a study, especially research with the title: "The Effect Of Intellectual Humility, Multicultural Personality, and Religious Orientation Toward Religious Tolerance on Students Of Universitas Islam Negeri Syarif Hidayatullah Jakarta”.

\section{Research Methods}

The population in this study were students of UIN Syarif Hidayatullah Jakarta. The criteria used in selecting the sample in this study are as follows: (1) Students of the State Islamic University Syarif Hidayatullah Jakarta, (2) Muslim, (3) minimum 4th semester, and (4) minimum age of 20 years. The sampling technique is a non-probability 
sampling technique with the purposive sampling method because it is based on criteria that are following the purpose of this study. The number of participating samples was 360 students from various faculties, followed by 141 men and 219 women with an age range between 20 and 25 years.

The measuring instrument of this study used a Likert scale with 4 scales, ranging from Totally Disagree (Sangat Tidak Setuju-STS), Disagree (Tidak Setuju-TS), Agree (Setuju-S), and Totally Agree (Sangat Setuju-SS). The process of analyzing the validity of the measuring instrument in this study used Confirmatory Factor Analysis (CFA). After testing the validity of the measuring instrument, the next process is an analysis using multiple regression with the help of IBM SPSS 21 software.

\section{Religious Tolerance Scale}

The measuring instrument used in measuring religious tolerance was compiled and adapted from the theory developed by Rivka T. Witenberg (2007) with three dimensions, fairness, empathy, and reasonableness as many as 30 items. Testing this measuring instrument produces a coefficient of fit index in the form of chisquare $=623.37, \mathrm{df}=312, \mathrm{RMSEA}=0.05 \mathrm{p}$ value for test of close fit (RMSEA $<0.05)=$ 0.22 , percent confidence interval for RMSEA $=(0.047 ; 0.059)$. The religious tolerance model with the index coefficient can be said to be fit (Browne \& Cudeck, 1992; Clogg \& Bollen, 1991; Jöreskog \& Sörbom, 1993).

\section{Intellectual Humility Scale}

The intellectual humility measuring instrument uses the Comprehensive Intellectual Humility Scale (CHIS) adapted to the Indonesian context as many as 22 items (Krumrei-mancuso \& Rouse, 2016). This measuring instrument has quite good psychometric properties, namely p-value:
0.793, RMSEA: 0.46, 90\% CI 0.039-0.054]. After being tested on the respondents of this study, the model generated by this measuring instrument is chi-square $=156.87, \mathrm{df}=133$, $\mathrm{p}$ value $=0.077, \mathrm{RMSEA}=0.02$.

\section{Multicultural Personality Scale}

Meanwhile, for multicultural personality, we used the Multicultural Personality Questionnaire Short Form (the MPQ-SF) which consists of five dimensions, cultural empathy, open-mindedness, emotional stability, flexibility, and social initiative which consists of 39 items. All dimensions in this measuring instrument have good quality validity test results. The dimension of cultural empathy has $p$-value $=0.144$ and RMSEA $=0.035$. The open-mindedness dimension has p-value $=0.060$ and RMSEA $=0.041$. Then the emotional stability dimension has $\mathrm{p}$-value $=0.074$ and RMSEA $=$ 0.04 . While the flexibility dimension has a $\mathrm{p}$ value $=0.14$ and $\mathrm{RMSEA}=0.03$. Finally, the social initiative dimension has $\mathrm{p}$-value $=0.085$ and RMSEA $=0.043$.

\section{Religious Orientation Scale}

As for measuring religious orientation, we used the New Indices of Religious Orientation (NIRO) with three dimensions, quest religiousness, intrinsic religiousness, and extrinsic religiousness as many as 18 items. (Francis, 2007). In this measuring tool, the construct validity test produces a fit model with an index, for the religiousness quest dimension it has $\mathrm{p}$-value $=0.108$ and RMSEA $=0.047$. The intrinsic religiousness dimension has $\mathrm{p}$-value $=0.324$ and RMSEA $=0.021$. Finally, the extrinsic religiousness dimension has $\mathrm{p}$-value $=0.265$ and $\mathrm{RMSEA}=0.028$.

\section{Results and Discussion}

Referring to table 1 below, it can be seen that the R Square of 0.510 is obtained. This indicates that religious tolerance is 
explained by all independent variables in this study with a variance proportion of $51 \%$, while the remaining $49 \%$ is influenced by other variables that are not explained in this study.

Tables, Figures, and Formulas

Table 1. Model Summary Model Summary

\begin{tabular}{c|c|c|c|c}
\hline $\begin{array}{c}\text { Mod } \\
\text { el }\end{array}$ & $\mathrm{R}$ & R Square & $\begin{array}{c}\text { Adjusted } \\
\text { R Square }\end{array}$ & $\begin{array}{c}\text { Std. } \\
\text { Error } \\
\text { of the } \\
\text { Estima } \\
\text { te }\end{array}$ \\
\hline 1 & $.714 \mathrm{a}$ & .510 & .497 & $\begin{array}{l}7.0897 \\
9\end{array}$ \\
\hline
\end{tabular}

a. Predictors: (Constant), Extrinsic Religiousness, Emotional Stability, Intellectual Humility, Quest Religiousness, Flexibility, Cultural Empathy, Social Initiative, Intrinsic Religiousness, Open-Mindedness

After knowing the proportion of variance, the next step is the F test to see the effect of all independent variables on religious tolerance is significant or not. Based on table 3 , it is known that the value of Sig. of 0.000 which means that it is significant with the provisions of the value is Sig. $<0.05$. This means that the null hypothesis which states that there is no significant effect of intellectual humility, multicultural personality, and religious orientation on religious tolerance is rejected. This indicates a significant influence between intellectual humility, multicultural personality, and religious orientation on religious tolerance.

Table 2. Anova

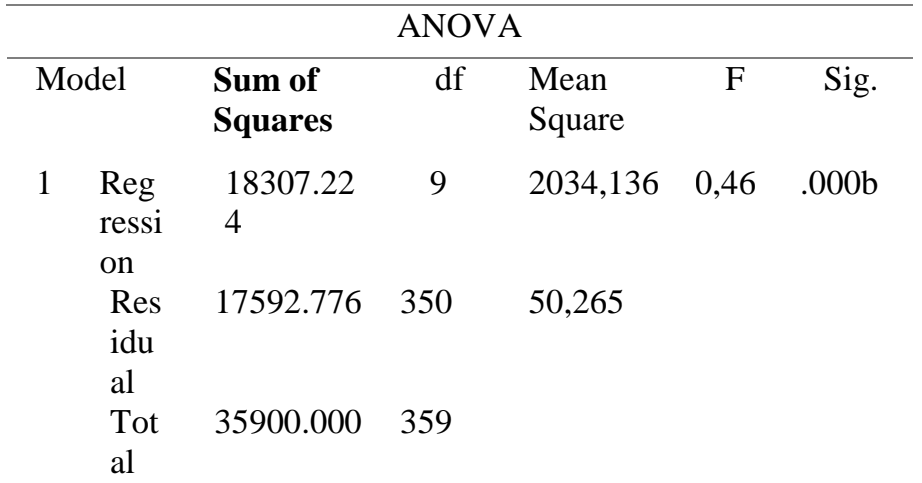

a. Dependent Variable: Religious Tolerance

b. Predictors: (Constant), Extrinsic Religiousness, Emotional Stability, Intellectual Humility, Quest Religiousness, Flexibility, Cultural Empathy, Social Initiative, Intrinsic Religiousness, Open-Mindedness

After testing F, the next step is to look at the regression coefficients of each of the variables studied on religious tolerance. The criteria used are if the value of Sig. $<0.05$, then the regression coefficient is significant for that variable. The following is the magnitude of the regression coefficient of each variable can be seen in Table 3 below.

\section{Table 3. Coefficients}

\begin{tabular}{|c|c|c|c|c|c|}
\hline \multicolumn{6}{|c|}{ Coefficients } \\
\hline \multirow[t]{2}{*}{ Model } & \multicolumn{2}{|c|}{ Unstand Coef } & \multirow{2}{*}{$\begin{array}{r}\text { Stand } \\
\text { Coef } \\
\text { Beta }\end{array}$} & \multirow[t]{2}{*}{$\mathrm{t}$} & \multirow[t]{2}{*}{ Sig. } \\
\hline & B & SE & & & \\
\hline 1(Cont. & 13,436 & 4.923 & & 2,729 & .007 \\
\hline $\mathrm{IH}$ & .532 & .046 & .532 & $\begin{array}{r}11,60 \\
3\end{array}$ & .000 \\
\hline $\mathrm{CE}$ & .229 & .050 & .229 & 4,601 & .000 \\
\hline $\mathrm{OM}$ & .135 & .064 & .135 & 2,094 & .037 \\
\hline ICE & .069 & .044 & .069 & 1.564 & .119 \\
\hline Flex & -.008 & .043 & -.008 & -179 & .858 \\
\hline SI & -.053 & .055 & -.053 & -.955 & .340 \\
\hline QR & .035 & .039 & .035 & .894 & .372 \\
\hline \multirow[t]{2}{*}{ IR } & -.185 & .054 & -.185 & - & .001 \\
\hline & & & & 3.426 & \\
\hline ER & -.023 & .050 & -.023 & -.456 & .649 \\
\hline \multicolumn{6}{|c|}{ a. Dependent Variable: Religious Tolerance } \\
\hline \multicolumn{6}{|c|}{$\begin{array}{r}\text { Religious Tolerance' }=13,436+0.532 \mathrm{IH}+0.229 \mathrm{CE}+ \\
0.135 \mathrm{OM}+0.69 \mathrm{ES}-0.008 \\
\text { Flex }-0.053 \mathrm{SI}+0.035 \mathrm{QR} \\
-0.185 \mathrm{IR}-0.023 \mathrm{ER}\end{array}$} \\
\hline
\end{tabular}

From table 4 which refers to the criteria of Sig. $<0.05$, it can be seen that four variables have a significant influence on religious tolerance, namely intellectual humility, cultural empathy, open-mindedness, and intrinsic religiousness, while the other five variables have an insignificant effect on religious tolerance.

Referring to the results of the research above, the intellectual humility (IH) variable has the largest proportion of influence which is $44.2 \%$ on religious tolerance. The results of this study are supported by other studies which 
explain that IH has a positive correlation with the forgiveness of religious leaders, even in conflict situations. (Hook et al., 2015; Zhang et al., 2015). When a religious follower has a high IH, they will see the person who persecutes him, forgiveness. In other contexts such as when discussion forums and debates are good about trust, politics, social and economics, IH becomes a catalyst in minimizing unnecessary conflicts. (Rodriguez et al., 2017). This can happen because, IH is characterized by openness in dealing with differences, being polite when dealing with conflicts between ideologies, religions, and so on, willingness to be open and learn new things and minimize personal ego towards differences. The ownership of IH's attitude towards everyone becomes an important asset when in a religious situation, in this case, differences in religion to tolerate each other (Hook et al., 2016; Mcelroy et al., 2014).

Multicultural personality variable has dimensions of cultural empathy, openmindedness, emotional stability, flexibility, and social initiative. The dimension of cultural empathy has a $3.3 \%$ effect and significantly explains religious tolerance. This is also in line with previous research which explains that cultural empathy is a predictor of the emergence of tolerance (Gawali \& Khattar, 2016; LD Korol, 2017; LD Korol \& Cabral, 2016). Empathy is also part of the dimension of religious tolerance according to Witenberg's theory.

This means having empathy for the culture or what other people live will foster tolerance. Empathizing with others will certainly be warmly responded to by other people even though they have different cultures or attributes from themselves. This is reflected in other studies that show empathy for different cultures increases positive attitudes towards people who have different attributes such as race, religion, and so on. (L. Korol, 2018).
Another dimension is openmindedness which has a positive and significant influence on religious tolerance. The focus is on openness and not having a prejudice against those who have different religions and values from themselves or their group(K. Van Der Zee et al., 2013; KI Van Der Zee \& Oudenhoven, 2001). Open individuals will tend to be without prejudice, even though what other people bring they don't agree with but still show enthusiasm for it. An open mind is a reflection of a person who is broadminded, flexible, intellectual, and an extraordinary thinker(Butrus \& Witenberg, 2013).

The next dimension is emotional stability, which has a positive but not significant effect in explaining religious tolerance. The results of this study support previous studies that are influential but not significant(Gawali \& Khattar, 2016). Emotional stability showed insignificant results probably because this dimension is more about the struggle within the individual, how the emotional changes that occur to him.

The dimensions of flexibility and social initiative showed no significant effect on religious tolerance. For the flexibility dimension, it may occur because of the weakness of the item that does not test the unfavorable item so that there may be a bias that occurs. While the social initiative dimension is in line with previous research which has an effect but is not significant(LD Korol \& Cabral, 2016).

Another variable tested in this study is religious orientation. This variable has three dimensions, quest, intrinsic and extrinsic religiousness. Quest religiousness has a positive but not significant effect in explaining religious tolerance. It was found that the attitude of the quest characterizes people who are open to differences and continue to search, so they tend not to have a prejudice against 
differences(Altemeyer, 2003; Altemeyer \& Hunsberger, 1992).

The next dimension is intrinsic religiousness. This dimension has a negative and significant influence in explaining religious tolerance. When a person has a high intrinsic religious orientation, it is likely to have a low tolerance. This result is not in line with previous studies which tend to have low levels of prejudice and are more tolerant of differences(Allport \& Ross, 1967; Fisher et al., 1994).

The possibility is that there are differences in the respondents tested, in this study testing respondents from Islam against non-Muslims. The next dimension is extrinsic religiousness. The results of this dimension research show that it does not have a significant and negative effect. So are Allport \& Ross (1967) stated that people whose religious orientation is extrinsic will tend to be prejudiced against others because religious motives are driven by worldly things such as relationships, social, economic, and so on.

\section{Conclusion}

Based on the results of the research above, it can be concluded that the influence of intellectual humility, multicultural personality, and religious orientation on religious tolerance has an effect of $51 \%$ and the effect is significant. The contribution of the largest proportion of variance comes from the intellectual humility variable, which is $44.2 \%$. In addition, several variables have a significant effect, including intellectual humility, cultural empathy, open-mindedness, and intrinsic religiousness, while the rest have no significant effect on religious tolerance.

With this research, we hoped that there will be training on $\mathrm{IH}$ attitudes, especially utilizing frequent discussions and together in forums with people who have different religions. For example, students are allowed to participate in international forums whose participants have diverse backgrounds. This polite attitude, openness to new things, and accepting differences also need to be highlighted by religious leaders, political figures, and other influencers so that listeners can imitate what they are doing

The results of the influence of openmindedness on religious tolerance show the importance of cognitive flexibility and openmindedness during a diverse life. Cognitive flexibility helps individuals to be less rigid in thinking about change and difference. A diverse society, especially in religious differences, when living interacting with different people of course needs to adapt to that person.

In addition, it can be said that religious orientation is not only related to individual worship but also related to social aspects of religion. This means that aspects of worship are related to goodness in social life. This will foster high concern and empathy for people's lives, thereby minimizing the tension of being able to live the lives of others.

\section{References}

Allport, G. W. (1954). The Nature of Prejudice. Wesley Publishing Company. https://archive.org/details/TheNatureOfP rejudice/page/n1

Allport, G. W., \& Ross, J. M. (1967). Personal Religious Orientation and Prejudice. Journal of Personality and Social Psychology, 5(4), 432-443. https://psycnet.apa.org/record/200511100-004

Altemeyer, B. (2003). Research: Why Do Religious Fundamentalists Tend to be Prejudiced? The International Journal for the Psychology of Religion, 13(1), 17-28. https://doi.org/10.1207/S15327582IJPR1 301

Altemeyer, B., \& Hunsberger, B. (1992). The International Journal for the Fundamentalism, Quest, and Prejudice Authoritarianism , Religious Fundamentalism, Quest, and Prejudice. 
International Journal for the Psychology

of Religion, 2(2), 37-41. https://doi.org/10.1207/s15327582ijpr02 02

Apinino, R. (2018). Detail Kejadian Keluhan Suara Azan dan Kerusuhan di Tanjung Balai. Tirto.Id. https://tirto.id/detailkejadian-keluhan-suara-azan-dankerusuhan-di-tanjung-balai-cUg6

Batson, C. D., \& Schoenrade, P. A. (1991a). Measuring Religion as Quest: 1) Validity Concerns *. Journal for the Scientific Study of Religion, 30(4), 416429.

Batson, C. D., \& Schoenrade, P. A. (1991b). Measuring Religion as Quest: 2 ) Reliability Concerns *. Journal for the Scientific Study of Religion, 30(4), 430447.

BBC. (2017). Bagaimana agar intoleransi tak berlanjut sesudah pilkada DKI Jakarta. BBC.

https://www.bbc.com/indonesia/indonesi a-42042632

Browne, M. W., \& Cudeck, R. (1992). Alternative Ways of Assessing Model Fit. Sociological Methods \& Research, 21(2), 230-258.

https://doi.org/10.1177/00491241920210 02005

Butrus, N., \& Witenberg, R. T. (2013). Some personality predictors of tolerance to human diversity: The roles of openness, agreeableness, and empathy. Australian Psychologist, 48(4), 290-298. https://doi.org/10.1111/j.17429544.2012.00081.x

Clogg, C. C., \& Bollen, K. A. (1991). Structural Equations with Latent Variables. In Contemporary Sociology (Vol. 20, Issue 1). https://doi.org/10.2307/2072165

CNN Indonesia. (2019). Rentetan Bom dan Aksi Terorisme Selama Ramadhan di Indonesia. CNN. https://www.cnnindonesia.com/nasional/ 20190604110800-20-400871/rentetanbom-dan-aksi-terorisme-selamaramadan-di-indonesia

Duta. (2019). The Santri dan Hukum Membuat Film Menabrak Akidah Menurut Gus
Qoyyum. Duta.Co. https://duta.co/thesantri-dan-hukum-membuat-filmmenabrak-akidah-menurut-gus-qoyyum

Fauzan, A. (2018). Mahasiswa Non Muslim Dapat Belajar di UIN Jakarta. Kabar Kampus.

http://kabarkampus.com/2018/07/mahasi swa-non-muslim-dapat-belajar-di-uinjakarta/

Fisher, R. D., Derison, D., Polley, C. F., Cadman, J., \& Johnston, D. (1994). Religiousness, Religious Orientation, and Attitudes Towards Gays and Lesbians. Journal of Applied Social Psychology, 24(7), 614-630. https://doi.org/10.1111/j.15591816.1994.tb00603.x

Francis, L. J. (2007). Introducing the New Indices of Religious Orientation ( NIRO ): Conceptualization and measurement. Mental Health, Religion \& Culture, 10(6), 585-602. https://doi.org/10.1080/13674670601035 510

Gawali, G. S., \& Khattar, T. (2016). The Influence of Multicultural Personality on Attitude Towards Religious Diversity Among Youth. Journal of the Indian Academy of Applied Psychology, 42(June), 114-123.

Hook, J. N., Davis, D. E., Tongeren, D. R. Van, Hill, P. C., Everett, L., Jr, W., Farrell, J. E., \& Dieke, P. (2015). Intellectual humility and forgiveness of religious leaders. The Journal of Positive Psychology, 37-41. https://doi.org/10.1080/17439760.2015.1 004554

Hook, J. N., Farrell, J. E., Johnson, K. A., Van, D. R., Davis, D. E., Aten, J. D., Hook, J. N., Farrell, J. E., Johnson, K. A., Van, D. R., Davis, D. E., \& Aten, J. D. (2016). Intellectual humility and religious tolerance. The Journal of Positive Psychology, 9760(May). https://doi.org/10.1080/17439760.2016.1 167937

Hukmana, S. Y. (2019). Radikalisme dan Intoleransi Mengganggu Ketenangan Pemilu. Medcom.Id. https://www.medcom.id/pemilu/news- 
pemilu/akWGBR3k-radikalisme-danintoleransi-mengganggu-ketenanganpemilu

Jöreskog, K. G., \& Sörbom, D. (1993). Structural Equation Modeling with the Simplis Command Language.

Kementerian Agama RI. (2010). Toleransi beragama mahasiswa (Studi tentang Pengaruh Kepribadian, Keterlibatan Organisasi, Hasil Belajar Pendidikan Agama, dan Lingkungan Pendidikan terhadap Toleransi Mahasiswa Berbeda Agama pada 7 Perguruan Tinggi Umum Negeri) (Bahari (ed.)). Badan Litbang dan Diklat Kementerian Agama.

Korol, L. (2018). Does multicultural personality moderate the relationship between cross-group friendship and allophilia? Journal of Social Psychology, 159(6), 649-663. https://doi.org/10.1080/00224545.2018.1 549012

Korol, L. D. (2017). Is the Association Between Multicultural Personality and Ethnic Tolerance Explained by CrossGroup Friendship? Journal of General Psychology, 144(4), 264-282. https://doi.org/10.1080/00221309.2017.1 374118

Korol, L. D., \& Cabral, G. G. M. (2016). The influence of multicultural personality on attitude towards. Psicologia: Teoria $e$ Pratica, 18(2), 57-74.

Krumrei-mancuso, E. J. (2016). Intellectual humility and prosocial values : Direct and mediated effects Intellectual humility and prosocial values: Direct and mediated effects. The Journal of Positive Psychology, 9760(June). https://doi.org/10.1080/17439760.2016.1 167938

Krumrei-mancuso, E. J., \& Rouse, S. V. (2016). The Development and Validation of the Comprehensive Intellectual Humility Scale. Journal of Personality Assessment, 98(2), 209-221. https://doi.org/10.1080/00223891.2015.1 068174

Maimanah. (2013). Wanita dan Toleransi Beragama ( Analisis Psikologis ). Mu`adalah Jurnal Studi Gender Dan
Anak, 1(1), 51-58.

Mcelroy, S. E., Rice, K. G., Davis, D. E., Hook, J., Hill, P. C., Worthington, E. L. J., \& Tongeren, D. R. Van. (2014). Intellectual Humility: Scale Development and Theoretical Elaborations in the Context of Religious Leadership. Journal of Psychology \& Theology, 42(1), 19-30. https://doi.org/10.1177/00916471140420 0103

Mummendey, A., \& Wenzel, M. (1999). Social Discrimination and Tolerance in Intergroup Relations: Reactions to Intergroup Difference. Personality and Social Psychology Review, 3(2), 158174.

https://doi.org/10.1207/s15327957pspr03 02

Noor, T. R. (2018). Meneropong Indonesia: Sebuah Analisis Sosiologis dan Psikologis Atas Konflik Benuansa Keagamaan Di Indonesia. Journal AnNafs; Kajian Penelitian Psikologi, 3(2), 135-150.

https://doi.org/10.33367/psi.v3i2.499

Oudenhoven, J. P. Van, \& Zee, K. I. Van Der. (2002). Predicting multicultural effectiveness of international students: the Multicultural Personality Questionnaire. International Journal of Intercultural Relations, 26, 679-694.

Rodriguez, D., Hook, J. N., Farrell, J. E., Mosher, D. K., Zhang, H., Tongeren, D. R. Van, Davis, D. E., Aten, J. D., Hill, C., Rodriguez, D., Hook, J. N., Farrell, J. E., Mosher, D. K., Zhang, H., Tongeren, D. R. Van, Davis, D. E., Aten, J. D., \& Hill, P. C. (2017). Religious intellectual humility, attitude change, and closeness following religious disagreement. The Journal of Positive Psychology, 9760(October), 1-8. https://doi.org/10.1080/17439760.2017.1 388429

Tongeren, D. R. Van, Hakim, S., Hook, J. N., Johnson, K. A., Green, J. D., Hulsey, T. L., Davis, D. E., Tongeren, D. R. Van, Hakim, S., Hook, J. N., Johnson, A., Green, J. D., Hulsey, T. L., \& Davis, D. E. (2016). Toward an Understanding of 
Religious Tolerance: Quest Religiousness and Positive Attitudes Toward Religiously Dissimilar Others Toward an Understanding of Religious Tolerance: Quest Religiousness and Positive Attitudes Toward Religiously Dissimilar. The International Journal for the Psychology of Religion, OO(March 2016), $1-13$. https://doi.org/10.1080/10508619.2015.1 039417

Tongeren, D. R. Van, Stafford, J., Hook, J. N., Green, J. D., Davis, D. E., Johnson, K. A., Tongeren, D. R. Van, Stafford, J., Hook, J. N., Green, J. D., Davis, D. E., \& Johnson, K. A. (2016). Humility attenuates negative attitudes and behaviors toward religious out-group members. The Journal of Positive Psychology, 9760(February). https://doi.org/10.1080/17439760.2015.1 037861

Tsang, J. A., \& Rowatt, W. C. (2007). The relationship between religious orientation, right-wing authoritarianism, and implicit sexual prejudice. International Journal for the Psychology of Religion, 17(2), 99-120. https://doi.org/10.1080/10508610701244 122

Verkuyten, M. (2010). Multiculturalism and Tolerance An Intergroup Perspective. In R. J. Crisp (Ed.), The Psychology of Social and Cultural Diversity (pp. 1-25). Blackwell Publishing.

Verkuyten, M., \& Yogeeswaran, K. (2016). The Social Psychology of Intergroup Toleration: A Roadmap for Theory and Research. Personality and Social Psychology Review, 1-25. https://doi.org/10.1177/10888683166409 74

Witenberg, R T. (2019). 1 . 1 What is Tolerance : Competing Interpretations. In The Psychology of Tolerance. SpringerBriefs in Psychology. https://doi.org/10.1007/978-981-133789-5

Witenberg, Rivka T. (2007). The moral dimension of children' $\mathrm{s}$ and adolescents ' conceptualisation of tolerance to human diversity. Journal of Moral Education, January 2015, 37-41. https://doi.org/10.1080/03057240701688 002

Witenberg, Rivka T. (2019). The Psychology of Tolerance Conception and Development. Springer.

Zee, K. I. Van Der, \& Oudenhoven, J. P. Van. (2000). The multicultural personality questionnaire- A multidimensional instrument of multicultural effectivenes. European Journal of Personality, 14, 291-309.

Zee, K. I. Van Der, \& Oudenhoven, J. P. Van. (2001). The Multicultural Personality Questionnaire: Reliability and Validity of Self- and Other Ratings of Multicultural Effectiveness Karen I. Van der Zee and Jan Pieter Van Oudenhoven. Journal of Research in Personality, 288, 278-288. https://doi.org/10.1006/jrpe.2001.2320

Zee, K. Van Der, Oudenhoven, J. P. Van, Ponterotto, J. G., \& Alexander, W. (2013). Multicultural Personality Questionnaire : Development of a Short Form Multicultural Personality Questionnaire : Development of a Short Form. Journal of Personality Assessment, 95(1), 37-41. https://doi.org/10.1080/00223891.2012.7 18302

Zhang, H., Farrell, J. E., \& Hook, J. N. (2015). Intellectual Humility and Forgiveness of Religious Conflict. Journal of Psychology \& Theology, 43(4), 255-262. https://doi.org/10.1177/00916471150430 0403 